\title{
4
}

\section{Mechanisms of Cell Death in the Transmissible Spongiform Encephalopathies}

\author{
Fiona Lane*, James Alibhai*, Jean C. Manson and Andrew C. Gill ${ }^{\dagger}$ \\ The Roslin Institute and R(D)SVS, University of Edinburgh, \\ Easter Bush Veterinary Centre, Roslin, Edinburgh \\ UK
}

\section{Introduction}

The transmissible spongiform encephalopathies (TSEs) constitute a family of fatal, neurodegenerative diseases, including scrapie in sheep, chronic wasting disease (CWD) in deer and elk, bovine spongiform encephalopathy (BSE) and a range of human disorders, such as Creutzfeldt-Jakob disease (CJD), kuru and fatal familial insomnia. The archetypal TSE disease is scrapie of sheep and goats, which has been present in the UK flock for over 200 years as a result of both horizontal and vertical transmission. The most prevalent TSE disease of humans is sporadic Creutzfeldt-Jakob disease (spCJD), which affects 1-3 individuals per million worldwide. A new form of CJD, known as variant CJD (vCJD), was diagnosed in humans in the mid 1990s and it is likely that vCJD was contracted by consumption of contaminated beef, since this disease is indistinguishable from BSE on transmission to a panel of mice (Bruce et al., 1997). To date, there have been 175 cases of vCJD in the UK and a further 49 cases across 11 other countries (www.eurocjd.ed.ac.uk, data correct as of Aug 2011).

During pathogenesis of TSE disease the principal molecular event is the conformational rearrangement of a normal, host protein called the prion protein. The normal form of the prion protein, PrPC, misfolds to a form known as PrPSc. PrPsc is insoluble and partially resistant to digestion by proteolytic enzymes that would usually recycle incorrectly folded proteins. PrPsc therefore accumulates in proteinaceous aggregates, including plaques and fibrils. The prion protein is ubiquitously expressed, but is most abundant in the central nervous system (CNS). Hence accumulation of PrPSc occurs principally in the brain, but peripheral lymphoreticular tissues can also accumulate proteinaceous deposits. The prion hypothesis suggests that PrPsc is the infectious agent in TSE diseases and that it catalytically causes nascent PrPC molecules also to misfold (Prusiner, 1998). TSEs exist as discrete strains of disease, which can be stably passaged in suitable hosts resulting in differences in incubation time, clinical signs and pathology. It is suggested that PrPSc exists in different conformations, which encode the information necessary to transmit each disease and cause the strain-specific pathology (Prusiner, 1998). As a result of the critical involvement of the prion protein in TSEs, these disorders are also known as prion diseases.

*These authors contributed equally to this work

tCorresponding Author 
At clinical end point of TSE disease, there is characteristic vacuolation in various areas of the brain, the exact locations of which depends on the infecting strain. Loss of neurons can also be detected at late stages of disease as can alterations in membrane morphology. Several excellent reviews cover neuropathology of animal (Jeffrey et al., 2011) and human (Kovacs \& Budka, 2009) diseases that is evident on post mortem examination. In general, there are good correlations between disease, neurodegeneration and prion protein aggregation in many TSE diseases, which has led to suggestions that PrPSc-containing aggregates are directly toxic to neurons. In vitro studies largely support this conjecture, but the evidence in vivo is less convincing. Even assuming that a misfolded form of the prion protein is responsible for neurotoxicity, the mechanisms that initiate the cascade leading to neuronal loss are unknown. It is also unknown whether loss of function of $\mathrm{PrPC}$, as it is sequestered from the cell surface into proteinaceous aggregates, plays a role in rendering neurons susceptible to degeneration. Reactive astrocytosis is evident during the clinical phase and whilst time course studies have also suggested that astrocytes are activated at earlier stages, it is not known to what these cells are responding. In this chapter we review briefly the state of knowledge of the processes leading the neurodegeneration in TSE diseases, with a particular focus on the earliest detectable events.

\section{Early morphological events in TSE-induced neuronal loss}

In both prion diseases and other neurodegenerative disorders, the mechanisms leading to neurodegeneration remain particularly poorly understood. As mentioned above, the clinical phase of a variety of natural prion diseases has been studied, which has produced descriptions of the targeting of pathology, including the localisation of $\mathrm{PrPsc}$ deposits and of characteristic vacuolation and spongiform alterations. Substantial neuronal loss occurs by terminal endpoint, but it has become clear that loss of neurons is a relatively late development in the progression of pathology. In common with other neurodegenerative diseases, at later time points there are characteristic abnormalities in a range of normal neuronal molecular processes; this includes defects in ion homeostasis, aberrant mitochondrial morphologies and function, increased production of reactive oxygen species, endoplasmic reticulum stress and reduced proteasome function. Many of these homeostatic defects are thought to drive each other and it is therefore not clear which, if any, is the initiating factor. Thus, gross defects in several biochemical pathways represent the end stages of disease, but to determine causal mechanisms, it is necessary to describe in molecular and morphological detail the earliest stages of the neurodegenerative process. In naturally-contracted diseases, such descriptive studies are frequently not possible because (i) it is difficult to diagnose disease in advance of clinical signs (ii) outbred animals and humans can show significant variability in specific responses to disease and (iii) it is often impossible to know how and when individuals became infected. To remedy this situation, much use has been made of rodents as models of prion disease; C57BL/ 6 mice infected with the ME7 murine scrapie strain is the experimental system that has been studied in the greatest detail. There are clear advantages in using experimental prion diseases as a model, since the disease begins and ends at defined points (inoculation and death) and the homogeneity afforded by inbreeding produces standardised results. One caveat to murine models is that it appears that not all aspects of TSE disease in rodents are replicated in natural disease of large animals (Jeffrey et al., 2011). Nevertheless, some key findings from study of ME7 infection of mice are depicted graphically in Figure 1 and discussed below. 


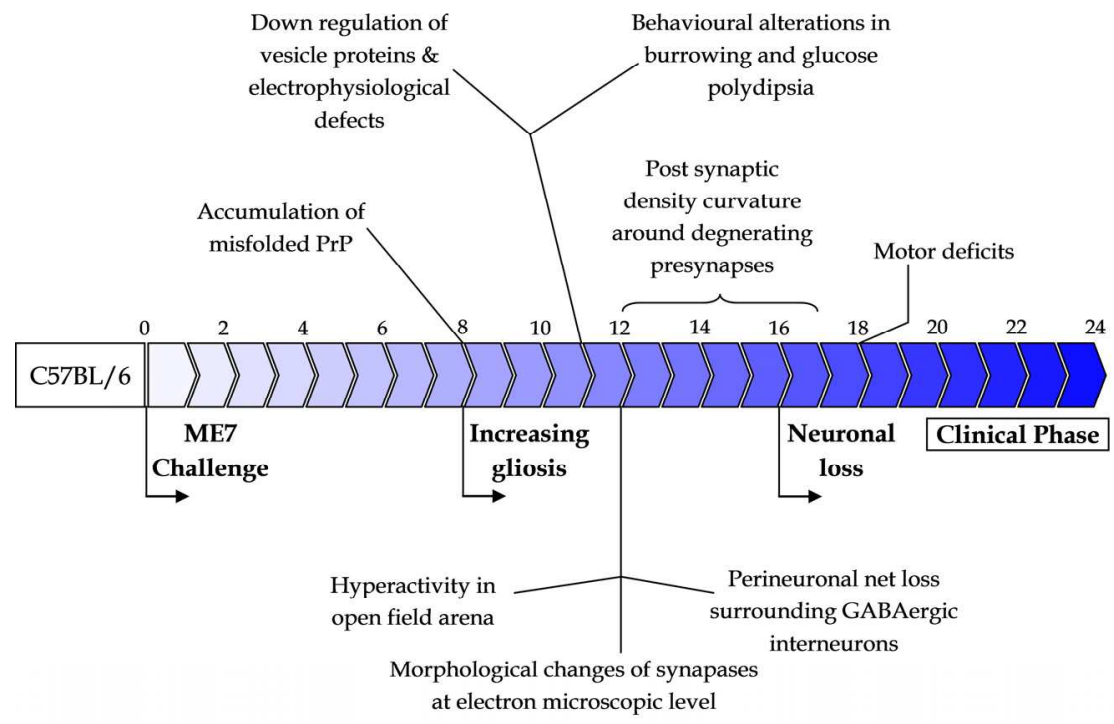

Fig. 1. Schematic timeline, in weeks, of pathological and behavioural events during infection of C57BL/ 6 mice with the mouse-passaged prion stain ME7. Information contained in this figure has been abstracted from multiple publications, referenced in section 2 .

\subsection{Synaptic degeneration precedes neuronal loss in prion disease}

Recent studies of the pathogenesis of the ME7 strain of murine scrapie have allowed the identification of synaptic deficits within the hippocampus of C57BL/6 mice that occur well before neuronal loss can be observed (Betmouni et al., 1999, Cunningham et al., 2003, Guenther et al., 2001, Jeffrey et al., 2000). From roughly half way though the incubation period, synaptic deficits can be characterised at a molecular level by a loss of integral synaptic vesicle proteins and reduced synaptophysin staining (Cunningham, et al., 2003, Cunningham et al., 2005, Gray et al., 2009). Importantly, molecular changes appear to correlate with functional deficits, since electrophysiological abnormalities have also been observed within a similar timeframe (Chiti et al., 2006). At week 12, an accumulation of electron rich material within the pre-synapse in the CA1 region of the hippocampus was observed by use of electron microscopy, specifically between CA3 pre-synapses and CA1 post-synaptic densities within the Schaffer-Collateral pathway (Siskova et al., 2009). As the disease progressed, a distinct curvature of the post-synaptic densities around the degenerating pre-synapses could be visualised (Siskova, et al., 2009), potentially an attempt to maximise synaptic transmission. In addition, a loss of perineuronal nets surrounding GABAergic interneurons of the hippocampus coincided with a reduction in synaptic plasticity at early time-points (week 11/12) (Franklin et al., 2008). Early synaptic changes are a feature of other strains of murine disease, suggesting that these events may be early pathological markers of a TSE infection (Siso et al., 2002), at least in rodents. Synaptic dysfunction also appears to be a consistent, early pathological sign in many other neurodegenerative diseases, but there are suggestions that the exact morphological changes seen may differ depending on whether the insults to synapses are caused by processes 
leading to intra- or extra-cellular protein deposits. In addition, synaptic dysfunction in prion diseases differs from that seen during Wallerian degeneration in the periphery, in which axons are dissected or otherwise compromised and presynapses retract (Gillingwater et al., 2003). In prion diseases, loss of synapses appears to be followed by a retraction of the dendritic spine, but whether loss of any given synapse impacts on neighbouring synapses and ultimately on the respective cell body remains to be determined.

The early loss of synapses in prion disease must occur in response to a disease-associated molecular event or biochemical pathway. It is possible that this event may be the beginnings of the misfolded protein cascade, since in C57BL/6 mice infected with ME7 scrapie the accumulation of PrPSc can be detected at week 8, before the first observable signs of synaptic defects. The first deposits of abnormal PrP accumulate in the dentate gyrus of the hippocampus, subsequently spreading to encompass the CA3 sub-region of the hippocampus (Gray, et al., 2009). This suggests a progression of PrPsc formation along the Mossy-Fibre pathway, connecting the dentate gyrus and CA3 field, and a subsequent pathological dysfunction of CA3 neurons leading to degeneration of CA3 pyramidal cell pre-synapses in the CA1 region along the Schaffer-Collateral pathway. In the majority of prion diseases that have been studied in detail, $\mathrm{PrPsc}$ accumulation is one of the earliest detectable pathological signs and precedes, or is concurrent with, cellular or synaptic changes. These results suggest a causative correlation between the initial signs of $\operatorname{PrP}$ conversion and synaptic dysfunction. This raises the question of whether neurodegenerative processes are also similar in other prion disease models, particularly those that have small quantities of misfolded PrP present at the clinical end point (Barron et al., 2007). In the majority of cases, time course studies of such disease models have not been performed in sufficient detail to dissect the earliest pathological events. It is clear, nevertheless, that synaptic dysfunction and degeneration occur well before neuronal loss is observed in TSEs.

\subsection{The role of glia in prion disease-induced neurodegeneration}

Although neuronal death in TSEs is the most widely recognised pathological manifestation at a cellular level, alterations in non-neuronal cells are also apparent occurring alongside the first obvious signs of $\mathrm{PrPSc}$ accumulation in the brain. Reactive astrogliosis, exemplified by up regulation of Gfap, can be seen in various areas of the brain (Betmouni et al., 1996, Cunningham, et al., 2003). An increased understanding of astrocytes suggests that these cells have an integral role in maintaining homeostatic functions within the CNS (Butt et al., 1994, Chang Ling \& Stone, 1991, Ransom et al., 2003, Robinson \& Dreher, 1989, Slezak \& Pfrieger, 2003). Astrocytic processes come into close contact with synapses (Bushong et al., 2004, Grosche et al., 1999) forming a 'tripartite' between the pre and post synaptic elements and the fine astrocytic processes (Araque et al., 2009). Astrocytes can undergo excitatory mediated release of chemical neurotransmitters as a result of increases of intracellular $\mathrm{Ca}^{2+}$ concentrations in the astrocyte cytoplasm (Kreft et al., 2009). Reactive astrogliosis is thought to play a neuroprotective role during acute brain injuries, for example during cerebral ischemia (Pekny et al., 2008), but it is not clear whether the activation of astrocytes is also neuroprotective during chronic infections, such as TSE diseases.

Microglia also exhibit an activated morphology prior to and concurrent with neurodegeneration, however, this doesn't appear to represent the classic inflammation one may expect during infection with classical pathogens (Perry et al., 2002). Instead, a concept 
of 'microglial priming' is thought to occur. Activated microglia produce an antiinflammatory phenotype in response to ongoing TSE pathology, but subsequent systemic insults can elicit a rapid inflammatory response, initially by increases in IL-1 $\beta$ (Perry et al., 2007, Perry et al., 2003). Since the microglial response is not associated with classic inflammation, the role that these cells play in neurodegenerative disease remains unknown. It has been hypothesised that microglia have a neurotoxic role in neurodegeneration (Block et al., 2007) but other studies suggest microglia could be neuroprotective (Solito et al., 2010). There are also suggestions that microglia are not involved in the neurodegenerative process at all, but that degeneration is a neuron-autonomous process, at least at early stages (Perry \& O'Connor, 2010). For both astrocytes and microglia, it remains unknown what these cells are responding to and whether this response aids or is detrimental to neuronal health. However, their activation at around the time that PrPsc deposition can first be observed suggests that they respond to the ongoing conversion process, to the accumulation of $\mathrm{PrPsc}$ itself or to the changes that PrP conversion and/or PrPSc deposition elicits in cellular mechanisms or synaptic morphology, plasticity and function. Mice in which PrPC expression is restricted to astrocytes are susceptible to TSE infection (Raeber et al., 1997) suggesting that these cells are important in replication of PrPSc as well as in responding to its presence. In many studies using the ME7 murine scrapie strain, there exists strong correlations between the initial accumulation of $\mathrm{PrPSc}^{\mathrm{Sc}}$ and neurodegeneration suggesting a key role for misfolded $\mathrm{PrP}$ in the mechanism of neuronal degeneration. This raises the key question of whether abnormal PrP isoforms are neurotoxic and, if so, what their molecular structures are.

\section{Molecular mechanisms underlying degeneration of neurons}

Prion protein deficient mice are resistant to TSE infection (Bueler et al., 1993, Manson et al., 1994b), demonstrating that $\mathrm{PrPC}$ is required for disease. However, it is unclear what property of $\mathrm{PrP}$ is important for pathology: whether the $\mathrm{PrPsc}$ that accumulates during disease is actually toxic to neurons directly, whether the loss of $\mathrm{PrPC}$ plays a role in rendering neurons susceptible to toxic insults (either involving $\mathrm{PrPsc}$ or not) or whether the ongoing process of agent replication compromises normal neuronal homeostasis. Although PrPSc accumulation appears to precede neuronal loss in ME7 scrapie, there are reasons to suggest that the accumulation of misfolded $\operatorname{PrP}$ is not responsible for neurotoxicity directly. For example (i) neurons which lack $\mathrm{PrPC}$ do not degenerate in the presence of infected graft tissue rich in PrPSc (Brandner et al., 1996) and (ii) a variety of models exist in which levels of PrPSc and neuronal loss are poorly correlated (Barron, et al., 2007, Baumann et al., 2007, Chiesa et al., 1998, Flechsig et al., 2003, Hegde et al., 1998, Lasmezas et al., 1997, Li et al., 2007, Ma et al., 2002, Muramoto et al., 1997, Piccardo et al., 2007, Shmerling et al., 1998). But if classical PrPSc is not neurotoxic, then what is the toxic species?

\subsection{Neurotoxicity of different aberrantly folded PrP isoforms}

Considerable morphological heterogeneity can be observed in the protein deposited in vivo and recombinant $\operatorname{PrP}(\mathrm{recPrP})$ also exhibits conformational flexibility in vitro. There are also reports of aberrant cell biological behaviour of $\mathrm{PrPC}$ at various stages of its cellular life-cycle, as depicted in figure 2, and these factors make pinpointing the neurotoxic entity rather challenging. Recent studies seem to support the idea that relatively small, (pre-fibrillar?) oligomeric protein species are highly neurotoxic (Bucciantini et al., 2002, Caughey \& 
Lansbury, 2003, Novitskaya et al., 2006, Simoneau et al., 2007, Zhang et al., 2010) and this appears true not just for prion diseases but also for other neurodegenerative protein misfolding diseases, further suggesting that common mechanisms of neurodegeneration may exist. RecPrP preparations have been used to investigate what the mechanisms underlying neuronal death may be, but in vitro studies such as these come with their own set of limitations. Nevertheless, a consensus from several studies suggests that oligomeric protein assemblies physically disrupt cellular membranes affecting the calcium levels within the cell (Sanghera et al., 2008, Simoneau, et al., 2007, Zhang, et al., 2010). This may occur by the insertion of oligomers into the phospholipid membrane (Kayed et al., 2004) and, since the plasma membrane is accessible to both intracellular and extracellular proteins, perturbation of the membrane may provide a mechanistic link between protein misfolding diseases that are associated with either intra- or extracellular deposits. An alternative theory is that functional structures, composed of oligomeric proteins, form within the lipid bilayer. These structures appear to act as relatively porous ion channels, affecting the cellular membrane potential and ionic homeostasis, leading to apoptosis (Quist et al., 2005).

In contrast to oligomers, fibrillar aggregates of recPrP have shown variable toxicity in vitro: some researchers have found that fibrils are not toxic to cells (Simoneau, et al., 2007), suggesting that fibril formation in vivo is a protective mechanism or an "end-point" in the misfolding pathway (Caughey \& Lansbury, 2003, Silveira et al., 2005). Conversely, other studies have shown fibrils to be just as toxic as oligomers (Novitskaya, et al., 2006), but since protein preparations are generally not extensively characterised prior to incubation with cells in vitro, it is possible that differences in protein structure may account for these inconsistencies. Although fibrils are typically perceived to be rather inert, it is also conceivable that smaller species could fragment from fibrillar aggregates, which may then possess the neurotoxic properties of oligomers (Tanaka et al., 2006). A study using A $\beta$ fibrils showed that interaction of the fibrils with lipids led to fragmentation, forming oligomers which were highly toxic (Martins et al., 2008). Thus the toxicity of amyloid fibrils may be inversely proportional to their stability. However, Novitskaya et al. showed that fibrils composed of recPrP caused cells to aggregate and subsequently undergo apoptosis, an effect that wasn't seen for oligomers in the same experiments (Novitskaya, et al., 2006). This aggregation was reduced when $\mathrm{PrPC}$ was down-regulated, suggesting a role for $\operatorname{Pr} P C$ in mediating toxicity. There have also been recent reports that $\mathrm{PrPC}$ is required for the toxicity exhibited by a range of molecular species (Resenberger et al., 2011a).

$\mathrm{PrPC}$ is expressed heavily at synapses and the misfolding process may initiate in and around the synaptic cleft. This localises all relevant molecular species in the compartment in which the first morphological changes are detected, but this is still someway short of proving that abnormal PrP is neurotoxic. Through ongoing studies in our laboratories, we are endeavouring to dissect the relationship between PrPSc, infectivity, neurotoxicity and mechanisms of neurodegeneration (Barron, et al., 2007, Bradford et al., 2009, Cancellotti et al., 2010, Cancellotti et al., 2005, Manson et al., 2001, Piccardo, et al., 2007, Tuzi et al., 2008, Tuzi et al., 2004). Through the use of several unique models of prion disease in mice, we are beginning to accumulate evidence suggesting that the levels of infectivity are not always dependent on the quantity of misfolded PrP present (Barron, et al., 2007, Piccardo, et al., 2007). In conjunction with studies on the neurotoxicity of misfolded recombinant prion proteins, this leads to the theory that specific subpopulations of PrP conformations represent 
either the infectious or neurotoxic agents of TSEs (Weissmann, 1991). The role of PrPC in neuronal toxicity is still controversial and prompts the question of whether a reduction in the levels of $\mathrm{PrPC}$ on the cell surface, as it is converted into PrPsc, is a critical factor in prion disease-specific neurodegeneration.

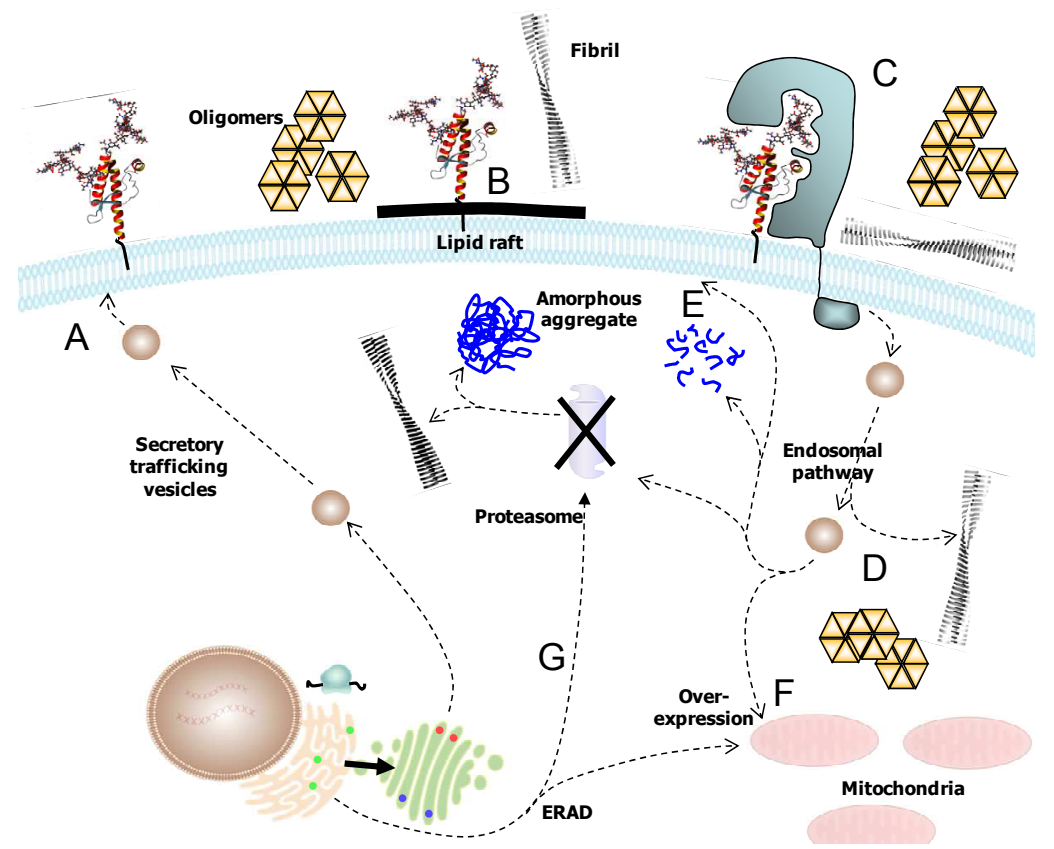

Fig. 2. Normal cell biology and putative misfolding pathways of PrP leading to toxicity. The prion protein is expressed in the secretory pathway and, after transiting the endoplasmic reticulum and Golgi apparatus, the protein is trafficked to the cell surface (A). Here it resides in specialised microdomains known as lipid rafts (B) but must move out of these domains to undergo endocytosis (C), presumably mediated by a cell surface receptor. After endocytosis $\mathrm{PrPC}$ is routed on the endosomal pathway (D). Both the cell surface and the endosomal pathway have emerged as candidate locations for prion protein misfolding to intra- and/or extra-cellular oligomers or fibrils. After trafficking through endosomes, a proportion of the protein can be degraded, whilst some of it is routed back to the cell surface (E). Over-expression of $\mathrm{PrPC}^{\mathrm{C}}$ results in its localisation in mitochondria $(\mathrm{F})$ whilst blockade of proteasome function leads to cytoplasmic accumulation $(\mathrm{G})$. Both processes may follow retrograde transport of PrP from the ER by endoplasmic reticulum associated degradation (ERAD) processes.

\subsection{Does loss of $\operatorname{PrP}^{\mathrm{C}}$ function play a role in neurodegeneration?}

The failure to infect prion protein knockout mice demonstrated conclusively that $\mathrm{PrPC}$ is needed to sustain prion disease (Bueler, et al., 1993, Manson, et al., 1994b). These animals were also expected to inform on $\operatorname{PrP}$ function, but initial observations suggested that knockout mice developed normally (Bueler et al., 1992, Manson et al., 1994a). More in depth studies have highlighted a range of subtle and not so subtle alterations, including abnormal 
circadian rhythms (Tobler et al., 1996), defects in long term potentiation (Curtis et al., 2003, Maglio et al., 2006) and abnormalities of mitochondrial numbers and morphologies (Miele et al., 2002). From additional studies, primarily in cells lacking $\operatorname{PrPC}$, there have been suggestions that $\mathrm{PrPC}$ has roles in copper binding and trafficking (Brown et al., 1997), the response to reactive oxygen species (Brown et al., 1999), neuritogenesis (Graner et al., 2000, Lopes et al., 2005) and calcium homeostasis (Colling et al., 1996, Fuhrmann et al., 2006, Herms et al., 2001). A key recent finding in PrPC knockout mice was defects in the maintenance of the myelin sheath surrounding peripheral nerves, a phenotype that appeared specifically to result from depletion of PrPC from neurons (Bremer et al., 2010). Thus, prion protein knockout mice have a range of physiological phenotypes primarily related to neuronal functions and this has led to a consensus that $\operatorname{PrPC}$ is a neuroprotective molecule, although it is not clear how, specifically, this neuroprotection is manifest (Resenberger et al., 2011b). A thorough review of prion protein function is beyond the scope of this chapter but, in the context of TSE disease, a key question is whether the loss of a neuroprotective function of $\mathrm{PrPC}$ plays a role in neurodegenerative mechanisms. Some intriguing observations came from experiments in which tissue from PrP-expressing mice was grafted into the brains of PrP knockout mice. After intracerebral prion infection, the grafted tissue developed pathology typical of prion disease, including PrPsc deposition, neuronal loss and vacuolation (Brandner, et al., 1996). However, despite PrPSc spreading from the grafted tissue into the surrounding brain area, no loss of PrP-null neurons was observed. These data strongly suggest that PrPSc is not neurotoxic in the absence of PrPC expression in neurons, results that were backed up by experiments in which $\operatorname{PrPC}$ expression in neurons was conditionally turned off in mice during an ongoing prion infection (Mallucci et al., 2003). Further evidence comes from infection of PrPC-GPI $/$ - mice (discussed further below), which do not express PrPC on the surface of neurons or indeed any neural cells (Chesebro et al., 2005). In GPI-/- mice, significant levels of PrPsc accumulated during disease but neuronal loss was not observed. These lines of evidence suggest that PrPC loss does not play a role in neurotoxicity and actually suggests the contrary - that normal neuronal PrPC expression is required for neurotoxicity (Resenberger, et al., 2011a).

Contradictory evidence comes from studies in PrPC-null mice transgenically expressing hamster PrPC exclusively on astrocytes; these mice were capable of supporting hamsterpassaged prion disease and developed clinical signs, indicating that neuronal $\mathrm{PrPC}^{\mathrm{C}}$ was not necessary for neuronal degeneration (Raeber et al., 1997). In the same studies, astrocytic hamster PrPC was expressed in mice in addition to wild type murine PrPC and these mice propagated hamster prion infectivity but did not develop disease, suggesting a role for mouse PrPC in protecting neurons from the toxicity of PrPSc. There are also several studies demonstrating that the toxicity of prion-related polypeptides is independent of the expression of $\mathrm{PrPC}$ on neurons. Hence, the role of $\mathrm{PrPC}$ in neurotoxicity is not clear and further understandings of how misfolded proteins can lead to synaptic degeneration and/or neurodegeneration will require a closer relationship between in vivo and in vitro studies. It seems likely that the initiation and progression of pathology leading from synaptopathy to neuronal loss requires a combination of (i) interaction of $\mathrm{PrPSc}$ with the synaptic membrane/vesicle membranes (ii) ongoing $\mathrm{PrPSc}^{\mathrm{Ps}}$ propagation (iii) loss of $\mathrm{PrPC}$ function and (iv) extracellular toxic PrPsc deposits. Since misfolding of $\mathrm{PrP}$ is required for the pathology associated with TSE disease, understanding the factors that aid this process will also aid our understanding of neurotoxicity and neuronal loss. 


\section{The mechanisms of prion protein misfolding leading to neuronal loss}

The prion protein is an obligatory component of TSE disease and its misfolding appears central to disease pathogenesis. Understanding how protein misfolding leads to pathology is of crucial importance but it is extremely challenging to study mechanistic aspects of protein folding and misfolding in vivo, hence in vitro studies have contributed almost all knowledge that currently exists in this area. This has involved solving and/or modelling structures of normal and aberrant forms of PrP and modelling the structural transition. The normal form of the protein has been investigated by use of recombinant prion proteins expressed in prokaryotic systems and refolded in vitro. The atomic level structures of such isoforms have been defined by both nuclear magnetic resonance (NMR) spectroscopy, for a range of different prion proteins e.g. (Calzolai et al., 2005, Christen et al., 2008, Gossert et al., 2005, Lysek et al., 2005, Perez et al., 2010, Wuthrich \& Riek, 2001), and X-ray crystallography for sheep (Eghiaian et al., 2004, Haire et al., 2004) human (Antonyuk et al., 2009, Knaus et al., 2001, Lee et al., 2010) and rabbit proteins (Khan et al., 2010). These studies found that the Cterminal region of PrP has globular structure (depicted in Fig 3) and NMR investigations of native PrPC purified from cattle brains confirmed these structural assignments (Hornemann et al., 2004).

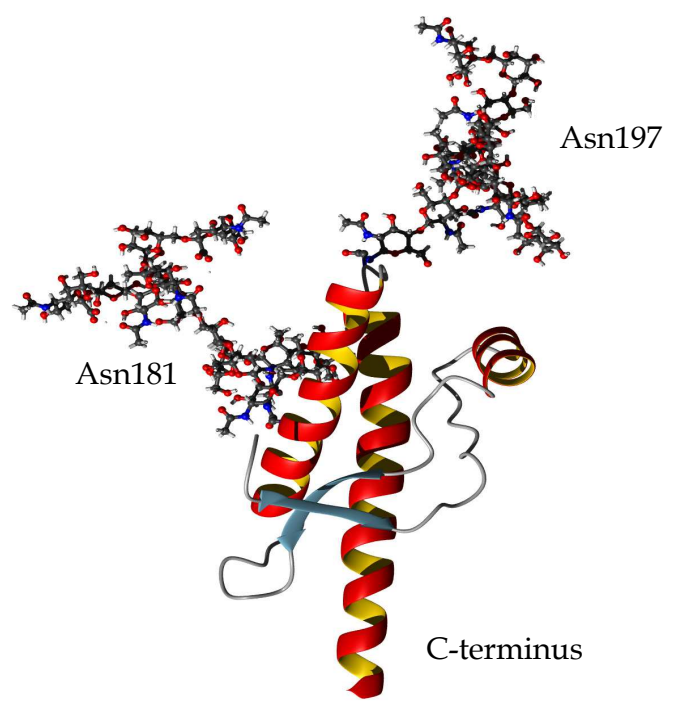

Fig. 3. The tertiary structure of PrPC with two average sized N-linked glycans added at the two N-linked consensus sites (human numbering), to scale, demonstrating the contribution that these moieties make to the total volume of the prion protein

By contrast, the $\mathrm{N}$-terminal region appears dynamically disordered. This domain incorporates 4-5 glycine-rich octapeptide repeats, which bind copper ions in vitro (Nadal et al., 2009, Pauly \& Harris, 1998, Whittal et al., 2000, Wong et al., 2000a) and possibly in vivo (Brown, et al., 1997, Waggoner et al., 2000) and the region also mediates the binding of $\mathrm{PrPC}$ to polyanionic compounds (Brimacombe et al., 1999). Although the N-terminal domain has been reported to be flexibly disordered, there have also been several reports of polyproline 
II structure in this region (Blanch et al., 2004, Gill et al., 2000, Taubner et al., 2010). The Nterminal region is present in the majority of PrPSc in diseased brains (Hope et al., 1986), but it seems to be dispensable for disease-specific misfolding, since transgenic mice expressing protein lacking the N-terminal domain are fully susceptible to disease (Fischer et al., 1996). The globular C-terminal region incorporates two consensus sites for $\mathrm{N}$-linked glycosylation, a single disulphide bond and a glycosylphosphatidyl inositol (GPI) membrane anchor is appended to the extreme C-terminus. After conversion of $\mathrm{PrPC}$ to $\mathrm{PrPSc}$, the C-terminal domain is resistant to protease digestion, indicating that it is this section of the protein that undergoes conformational change during prion protein misfolding.

By contrast to PrPC, atomic level detail of PrPSc tertiary structure is lacking, which is a result of the insolubility of PrPsc-containing aggregates and the heterogeneity of morphologies of these aggregates. The structure of PrPSc has been probed by use of several low resolution techniques and Fourier-transform infra red (FT-IR) spectroscopic analysis suggests that the transition from $\mathrm{PrPC}$ to $\mathrm{PrPS}^{\mathrm{Pc}}$ is associated with a partial increase in $\beta$-sheet structure (Caughey et al., 1991). Initially it was proposed that the second and third a-helices are not misfolded and theoretical structures followed, the most detailed of which is based upon empirical structural investigations by electron crystallography (Govaerts et al., 2004, Wille et al., 2002). However, recent data from hydrogen/deuterium-exchange experiments in conjunction with mass spectrometry has cast doubt on the existence of a-helical sections in PrPSc (Smirnovas et al., 2011). Instead, H/D exchange rates in $\mathrm{PrPSc}$ appear consistent with formation of $\beta$-sheet across the entire C-terminal domain, a result that challenges conventional wisdom of PrPsc structure. The problems associated with solving the structure of PrPsc appear insurmountable, at least at the present time and we are more likely to derive useful information from reasonable models of PrPSc.

\subsection{Misfolding of PrP can be modelled in vitro}

The structural transition from $\mathrm{PrPC}$ to $\mathrm{PrPsc}$ can be mimicked in vitro by a variety of techniques and this has allowed various determinants of protein misfolding to be investigated. By mixing together PrPsc and recPrP expressed in mammalian cell lines to result in newly protease resistant $\operatorname{PrP}(\mathrm{PrPRes})$ the group of Byron Caughey showed that $\mathrm{PrPSc}^{\mathrm{Sc}}$ can auto-catalytically seed the conformational conversion of recPrP (Kocisko et al., 1994). This technique was termed the cell free conversion assay (CFCA) and it was subsequently shown to mimic many aspects of disease seen in vivo, including species barriers (Kirby et al., 2003, Kocisko et al., 1995) and the inhibitory effects of specific chemicals (Caughey et al., 1998, Demaimay et al., 2000, Demaimay et al., 1998). Quantifying conversion efficiency allows insights into mechanistic aspects of conversion: for example, there are two distinct phases of prion protein conversion - binding followed by conformational alteration (Horiuchi \& Caughey, 1999) - and single amino acid substitutions were shown to dramatically affect the efficiency of conversion of the substrate (Bossers et al., 1997, Eiden et al., 2011, Kirby et al., 2010, Kirby et al., 2006). Furthermore, use of microsomes containing PrPSc and PrPC in CFCA reactions indicated that the two proteins must be in the same vesicle for conversion to take place (Baron et al., 2002).

More recently, a second generation of in vitro prion misfolding assays has arisen, principally in response to the need for improved prion diagnostics. By the use of exogenous sources of energy to agitate the classical CFCA reaction, coupled with replenishment of the substrate, 
conversion efficiencies can be dramatically enhanced. Conversion reactions driven by sonication or shaking have been developed and include methods known as protein misfolding cyclic amplification (PMCA) (Saa et al., 2006, Saborio et al., 2001), quaking induced conversion (QuIC) (Atarashi et al., 2011, Atarashi et al., 2008) and amyloid seeding assay (ASA) (Colby et al., 2007). The PMCA technique has also been shown to be capable of creating prion infectivity de novo from PrPC substrate in the absence of a PrPSc seed (Castilla et al., 2005). The protocols for CFCA, PMCA or QuIC assays differ in detail but generic principles underlie all such assays, as depicted in figure 4. In all cases a catalytic seed of PrPsc causes misfolding of a substrate, and this phenomenon firmly establishes that auto-catalytic, templated misfolding is a generic process in prion diseases. In addition to sources of physical energy, believed to aid fragmentation of large fibrils thereby generating fresh seed, many of the prion amplification techniques also require facilitation with other factors to amplify both infectivity and misfolded protein (Deleault et al., 2007, Wang et al., 2010). In this context, it is notable that several techniques exist to misfold recPrP in the absence of a physiological seed. Pathways leading to fibrils (Baskakov et al., 2002, Stohr et al., 2011) or oligomers (Rezaei, 2008, Tahiri-Alaoui et al., 2004, Tahiri-Alaoui et al., 2006) have been described, where misfolding is promoted by partially denaturing conditions. These processes occur comparatively rapidly and generally do not replicate features of disease, such as species barriers (Makarava et al., 2007) or polymorphic control of susceptibility (Baskakov et al., 2005, Kirby, et al., 2010), and also do not appear to generate bona fide prion infectivity (Legname et al., 2004, Makarava et al., 2010). These lines of evidence argue for a role for molecular cofactors in disease-specific prion protein misfolding (Birkmann \& Riesner, 2008, Gill et al., 2010, Graham et al., 2010). Identifying these co-factors in vivo will allow significant progress in the prevention of disease transmission.

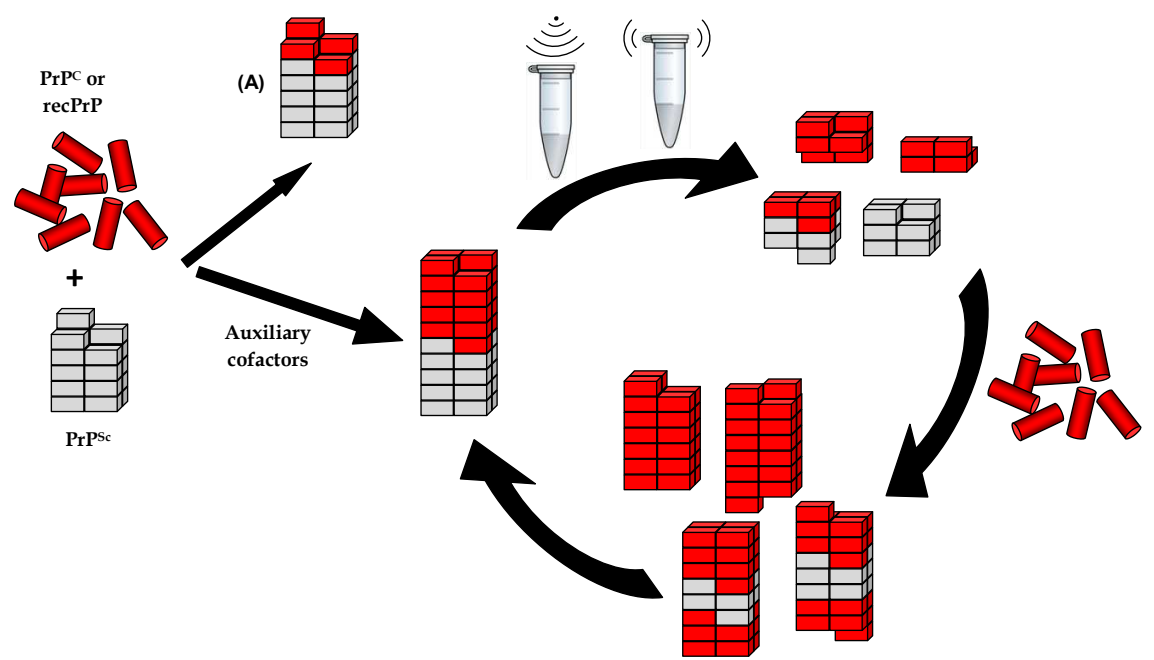

Fig. 4. Schematic pathways for seeded conversion of normal $\operatorname{PrP}$ to a protease-resistant isoform. In the absence of auxiliary cofactors, conversion is inefficient and only a small amount of available substrate is converted (A). This pathway is exemplified by the classic CFCA. By addition of auxiliary cofactors, conversion efficiency can be improved and periodic shaking (QuIC) or sonication (PMCA), coupled with replenishment of substrate, allows cyclic conversion leading to amplification of PrPRes 


\subsection{Factors contributing to prion protein misfolding}

Dramatic breakthroughs in the search for determinants of the prion protein misfolding process have been made in recent years. Deleault et al used the PMCA technique to amplify $\mathrm{PrPC}$ that had been highly purified from brain tissue to which polyanionic species (RNA or glycosaminoglycans) were added. This mixture was sufficient to allow amplification of abnormal PrP when seeded with PrPsc, but also allowed the generation of abnormal $\operatorname{PrP} d e$ novo in the absence of a catalytic seed. Crucially, the newly-synthesised abnormal PrP was shown to cause a TSE-like disease after inoculation to wild type animals. These data imply that purified $\operatorname{PrPC}$ (along with lipids that co-purified with the protein) in addition to a polyanionic cofactor are the minimal requirements for creation of prion infectivity (Deleault, et al., 2007). Various researchers have since replicated or extended this work (Barria et al., 2009, Edgeworth et al., 2010, Weber et al., 2007), culminating in the publication of a study describing prion infectivity, created de novo, from bacterially-expressed recPrP supplemented with just synthetic lipid and total RNA extracted from murine liver (Wang, et al., 2010). What are the identities of molecules playing the roles of cofactors in vivo?

One approach to determine in vivo cofactors is to investigate the aggregates present in prioninfected animals for molecules that may have played a role in their formation. Other than $\operatorname{PrP}$, various proteinaceous molecules appear specifically enriched in infectious prion fibrils (Giorgi et al., 2009, Moore et al., 2010, Petrakis et al., 2009) and recent data from our laboratory suggest that at least one such protein can enhance prion protein conversion efficiency (Graham et al., 2011). The most likely places for PrPC to encounter PrPSc and for conversion to take place are on the cell surface or within the endocytic pathway and it would appear reasonable to expect cofactors to reside in these locations. Results from experiments in cell lines supporting either location as a site for conversion have been published (Borchelt et al., 1992, Hooper, 2011). Recent data from our laboratories (Graham, et al., 2010, Graham, et al., 2011) and others (Abid et al., 2010), suggest that the plasma membrane is a more likely source of cofactors modulating prion protein misfolding. It is plausible that specific compositions of lipid can modulate prion protein structure thereby creating conditions for strain specific misfolding. Misfolding in or around the plasma membrane would facilitate toxic mechanisms that involve disturbances in membrane permeability. There are also various properties intrinsic to the prion protein that exert an influence on misfolding and which therefore may impact on neuronal toxicity of the resulting aggregates. Amino acid substitutions in the prion protein affect susceptibility of animals to prion disease and mutations in the human PRNP gene (encoding the prion protein) appear to be a direct cause of familial prion diseases. In general, those amino acid substitutions associated with resistance to prion disease in animals appear to decrease the stability of recombinant prion proteins in vitro (Bujdoso et al., 2005, Kirby, et al., 2010, Paludi et al., 2007, Thackray et al., 2004) potentially leading to differing levels of cellular toxicity. By contrast, there is conflicting data on the ability of mutations associated with human familial disease to affect the structure and stability of PrPC (e.g. (Apetri et al., 2004, Bae et al., 2009, Inouye et al., 2000, Rossetti et al., 2011, van der Kamp \& Daggett, 2010, Vanik \& Surewicz, 2002, Yin et al., 2007)) and there is a lack of clear data suggesting that human mutations confer increased neurotoxicity upon misfolded PrP. It seems likely that the effects of individual amino acid changes depend on the specific substitution as well as the position within the sequence of $\mathrm{PrPC}$ and potentially the species that the amino acid change is in. 
PrPC undergoes various post translational modifications in vivo and many have been investigated for their impact on prion protein misfolding. In transgenic mice that express prion protein lacking the C-terminal signal sequence, the GPI anchor is not attached (GPI- $/-)$ and this results in secretion of $\mathrm{PrPC}$ into the extracellular milieu. When GPI-/- mice are infected with a prion disease there is dramatic accumulation of large amyloid plaques composed of anchorless PrP but no evidence of neurodegeneration (Chesebro, et al., 2005). The reasons for this are unclear but presumably result from the lack of association of $\mathrm{PrPC}$ with the plasma membrane (Caughey et al., 2009), however, preventing GPI anchor addition also inhibits glycosylation of $\mathrm{PrPC}$ and this may be a compounding factor in the lack of pathology/disease. Nevertheless, as mentioned earlier, these results further indicate that large aggregates composed of prion protein are not neurotoxic per se.

N-linked glycosylation of PrPC occurs at two sites in the C-terminal region of the protein (Rudd et al., 2002) and a variety of techniques have been used to study the effect of glycosylation on prion protein misfolding. In vitro studies suggest that glycosylation of $\operatorname{PrPC}$ affects its interaction with PrPSc (Priola \& Lawson, 2001), but that glycosylation is not required for strain properties (Nishina et al., 2006, Piro et al., 2009). Initial reports from studies in cell lines suggested that removing prion glycosylation produced spontaneously misfolded protein (Lehmann \& Harris, 1997), however, this may have been a result of overexpression, since more recent studies have shown that blocking glycosylation of endogenously expressed PrPC does not produce this phenotype (Cancellotti, et al., 2005). In some cases, studies have been hampered by the folding and trafficking abnormalities that can occur when PrPC is expressed without glycosylation (Cancellotti, et al., 2005, DeArmond et al., 1997) depending on the specific mutations used to prevent glycosylation (Capellari et al., 2000, Ikeda et al., 2008, Salamat et al., 2011, Wong et al., 2000b). Neuendorf et al selected deglycosylating mutations that retained authentic $\mathrm{PrPC}$ cellular trafficking and mice in which these proteins were over-expressed were susceptible to both scrapie and BSE (Neuendorf et al., 2004). However, in some cases, incubation times were shorter than with wild type mice, which is probably an artefact of over-expression. In our laboratories we have produced gene-targeted mice lacking prion protein glycosylation (Cancellotti, et al., 2005) and analysis of these mice confirm that glycosylation is important for efficient trafficking of $\mathrm{PrPC}$, but that glycosylation is not always required to sustain prion infection after intracranial inoculation (Tuzi, et al., 2008). Intra-cranial infection of these mice with multiple prion strains indicates dramatically different requirements for occupation of each of the glycosylation sites of host PrP for infection. However, since disease outcomes are significantly modulated following peripheral infection of glycosylation-deficient, genetargeted mice, our data also suggest that glycosylation of $\mathrm{PrP}$ is important for either peripheral replication of PrPSc or for trafficking of the infection to the CNS (Cancellotti, et al., 2010). The glycans present at either site are highly heterogeneous (Ritchie et al., 2002, Rudd et al., 1999, Stimson et al., 1999); at least 60 different glycan moieties can be present on the protein and genetic removal of glycosylation does not distinguish between individual glycan structures. Thus, it is unclear whether any individual carbohydrate chains render the prion protein particularly susceptible to misfolding.

In summary, although we know the structure of $\mathrm{PrPC}$ to atomic resolution and we can model the conversion to PrPsc in vitro, the details of how this process takes place in vivo are still unknown. Although various factors are known to affect the way that PrPC may misfold, 
the only factor absolutely known to direct this process is exogenous PrPsc. It is assumed that the PrPSc catalysed misfolding of $\mathrm{PrPC}$ results in a species that is neurotoxic, but it remains possible that loss of $\mathrm{PrPC}$ is an important process in mediating neurotoxicity. Once neurotoxicity results, it appears clear that synaptic dysfunction is one of the first pathological alterations that can be detected. Approaches that integrate studies of protein misfolding, in vitro toxicity and in vivo toxicity are required to allow us to address the many unknowns of neuronal loss in prion disease

\section{Acknowledgements}

The authors would like to thank Drs Sandra McCutcheon and James F. Graham for constructive comments on the manuscript. FML and JA are supported by Doctoral Training Account scholarships from the BBSRC, UK. JCM and ACG acknowledge funding from a BBSRC Institute Programme Grant, the Department of Health, UK and the MRC, UK.

\section{References}

Abid, K., Morales, R. \& Soto, C. (2010). Cellular factors implicated in prion replication. FEBS Lett, Vol. 584, No. 11, pp. 2409-14

Antonyuk, S. V., Trevitt, C. R., Strange, R. W., Jackson, G. S., Sangar, D., Batchelor, M., Cooper, S., Fraser, C., Jones, S., Georgiou, T., Khalili-Shirazi, A., Clarke, A. R., Hasnain, S. S. \& Collinge, J. (2009). Crystal structure of human prion protein bound to a therapeutic antibody. Proc Natl Acad Sci U S A, Vol. 106, No. 8, pp. 2554-8

Apetri, A. C., Surewicz, K. \& Surewicz, W. K. (2004). The effect of disease-associated mutations on the folding pathway of human prion protein. J Biol Chem, Vol. 279, No. 17, pp. 18008-14

Araque, A., Perea, G. \& Navarrete, M. (2009). Tripartite synapses: astrocytes process and control synaptic information. Tr Neurosci, Vol. 32, No. 8, pp. 421-431

Atarashi, R., Satoh, K., Sano, K., Fuse, T., Yamaguchi, N., Ishibashi, D., Matsubara, T., Nakagaki, T., Yamanaka, H., Shirabe, S., Yamada, M., Mizusawa, H., Kitamoto, T., Klug, G., McGlade, A., Collins, S. J. \& Nishida, N. (2011). Ultrasensitive human prion detection in cerebrospinal fluid by real-time quaking-induced conversion. Nat Med, Vol. 17, No. 2, pp. 175-8

Atarashi, R., Wilham, J. M., Christensen, L., Hughson, A. G., Moore, R. A., Johnson, L. M., Onwubiko, H. A., Priola, S. A. \& Caughey, B. (2008). Simplified ultrasensitive prion detection by recombinant PrP conversion with shaking. Nat Methods, Vol. 5, No. 3, pp. 211-2

Bae, S. H., Legname, G., Serban, A., Prusiner, S. B., Wright, P. E. \& Dyson, H. J. (2009). Prion proteins with pathogenic and protective mutations show similar structure and dynamics. Biochemistry, Vol. 48, No. 34, pp. 8120-8

Baron, G. S., Wehrly, K., Dorward, D. W., Chesebro, B. \& Caughey, B. (2002). Conversion of raft associated prion protein to the protease-resistant state requires insertion of PrPres $(\operatorname{PrP}(\mathrm{Sc}))$ into contiguous membranes. Embo J, Vol. 21, No. 5, pp. 1031-40

Barria, M. A., Mukherjee, A., Gonzalez-Romero, D., Morales, R. \& Soto, C. (2009). De novo generation of infectious prions in vitro produces a new disease phenotype. PLoS Pathog, Vol. 5, No. 5, pp. e1000421 
Barron, R. M., Campbell, S. L., King, D., Bellon, A., Chapman, K. E., Williamson, R. A. \& Manson, J. C. (2007). High titers of transmissible spongiform encephalopathy infectivity associated with extremely low levels of PrPSc in vivo. J Biol Chem, Vol. 282, No. 49, pp. 35878-86

Baskakov, I., Disterer, P., Breydo, L., Shaw, M., Gill, A., James, W. \& Tahiri-Alaoui, A. (2005). The presence of valine at residue 129 in human prion protein accelerates amyloid formation. FEBS Lett, Vol. 579, No. 12, pp. 2589-96

Baskakov, I. V., Legname, G., Baldwin, M. A., Prusiner, S. B. \& Cohen, F. E. (2002). Pathway complexity of prion protein assembly into amyloid. J Biol Chem, Vol. 277, No. 24, pp. 21140-8

Baumann, F., Tolnay, M., Brabeck, C., Pahnke, J., Kloz, U., Niemann, H. H., Heikenwalder, M., Rulicke, T., Burkle, A. \& Aguzzi, A. (2007). Lethal recessive myelin toxicity of prion protein lacking its central domain. Embo J, Vol. 26, No. 2, pp. 538-47

Betmouni, S., Deacon, R. M. J., Rawlins, J. N. P. \& Ferry, V. H. (1999). Behavioral consequences of prion disease targeted to the hippocampus in a mouse model of scrapie. Psychobiology, Vol. 27, No. 1, pp. 63-71

Betmouni, S., Perry, V. H. \& Gordon, J. L. (1996). Evidence for an early inflammatory response in the central nervous system of mice with scrapie. Neuroscience, Vol. 74, No. 1, pp. 1-5

Birkmann, E. \& Riesner, D. (2008). Prion infection: seeded fibrillization or more? Prion, Vol. 2, No. 2, pp. 67-72

Blanch, E. W., Gill, A. C., Rhie, A. G., Hope, J., Hecht, L., Nielsen, K. \& Barron, L. D. (2004). Raman optical activity demonstrates poly(L-proline) II helix in the N-terminal region of the ovine prion protein: implications for function and misfunction. $J \mathrm{Mol}$ Biol, Vol. 343, No. 2, pp. 467-76

Block, M. L., Zecca, L. \& Hong, J. S. (2007). Microglia-mediated neurotoxicity: uncovering the molecular mechanisms. Nat Rev Neurosci, Vol. 8, No. 1, pp. 57-69

Borchelt, D. R., Taraboulos, A. \& Prusiner, S. B. (1992). Evidence for synthesis of scrapie prion proteins in the endocytic pathway. J Biol Chem, Vol. 267, No. 23, pp. 16188-99

Bossers, A., Belt, P., Raymond, G. J., Caughey, B., de Vries, R. \& Smits, M. A. (1997). Scrapie susceptibility-linked polymorphisms modulate the in vitro conversion of sheep prion protein to protease-resistant forms. Proc Natl Acad Sci U S A, Vol. 94, No. 10, pp. 4931-6

Bradford, B. M., Tuzi, N. L., Feltri, M. L., McCorquodale, C., Cancellotti, E. \& Manson, J. C. (2009). Dramatic reduction of PrPC level and glycosylation in peripheral nerves following $\operatorname{PrP}$ knock-out from Schwann cells does not prevent transmissible spongiform encephalopathy neuroinvasion. J Neurosci, Vol. 29, No. 49, pp. 15445-54

Brandner, S., Isenmann, S., Raeber, A., Fischer, M., Sailer, A., Kobayashi, Y., Marino, S., Weissmann, C. \& Aguzzi, A. (1996). Normal host prion protein necessary for scrapie-induced neurotoxicity. Nature, Vol. 379, No. 6563, pp. 339-43

Bremer, J., Baumann, F., Tiberi, C., Wessig, C., Fischer, H., Schwarz, P., Steele, A. D., Toyka, K. V., Nave, K. A., Weis, J. \& Aguzzi, A. (2010). Axonal prion protein is required for peripheral myelin maintenance. Nat Neurosci, Vol. 13, No. 3, pp. 310-8

Brimacombe, D. B., Bennett, A. D., Wusteman, F. S., Gill, A. C., Dann, J. C. \& Bostock, C. J. (1999). Characterization and polyanion-binding properties of purified recombinant prion protein. Biochem J, Vol. 342, No. 3, pp. 605-13 
Brown, D. R., Qin, K., Herms, J. W., Madlung, A., Manson, J., Strome, R., Fraser, P. E., Kruck, T., von Bohlen, A., Schulz-Schaeffer, W., Giese, A., Westaway, D. \& Kretzschmar, H. (1997). The cellular prion protein binds copper in vivo. Nature, Vol. 390, No. 6661, pp. 684-7

Brown, D. R., Wong, B. S., Hafiz, F., Clive, C., Haswell, S. J. \& Jones, I. M. (1999). Normal prion protein has an activity like that of superoxide dismutase. Biochem J, Vol. 344, No. 1, pp. 1-5

Bruce, M. E., Will, R. G., Ironside, J. W., McConnell, I., Drummond, D., Suttie, A., McCardle, L., Chree, A., Hope, J., Birkett, C., Cousens, S., Fraser, H. \& Bostock, C. J. (1997). Transmissions to mice indicate that 'new variant' CJD is caused by the BSE agent. Nature, Vol. 389, No. 6650, pp. 498-501

Bucciantini, M., Giannoni, E., Chiti, F., Baroni, F., Formigli, L., Zurdo, J., Taddei, N., Ramponi, G., Dobson, C. M. \& Stefani, M. (2002). Inherent toxicity of aggregates implies a common mechanism for protein misfolding diseases. Nature, Vol. 416, No. 6880, pp. 507-11

Bueler, H., Aguzzi, A., Sailer, A., Greiner, R. A., Autenried, P., Aguet, M. \& Weissmann, C. (1993). Mice devoid of PrP are resistant to scrapie. Cell, Vol. 73, No. 7, pp. 1339-47

Bueler, H., Fischer, M., Lang, Y., Bluethmann, H., Lipp, H. P., DeArmond, S. J., Prusiner, S. B., Aguet, M. \& Weissmann, C. (1992). Normal development and behaviour of mice lacking the neuronal cell-surface PrP protein. Nature, Vol. 356, No. 6370, pp. 577-82

Bujdoso, R., Burke, D. F. \& Thackray, A. M. (2005). Structural differences between allelic variants of the ovine prion protein revealed by molecular dynamics simulations. Proteins, Vol. 61, No. 4, pp. 840-9

Bushong, E. A., Marton, M. E. \& Ellisman, M. H. (2004). Maturation of astrocyte morphology and the establishment of astrocyte domains during postnatal hippocampal development. Int J Dev Neurosci, Vol. 22, No. 2, pp. 73-86

Butt, A. M., Colquhoun, K., Tutton, M. \& Berry, M. (1994). Three-dimensional morphology of astrocytes and oligodendrocytes in the intact mouse optic nerve. J Neurocytol, Vol. 23, No. 8, pp. 469-85

Calzolai, L., Lysek, D. A., Perez, D. R., Guntert, P. \& Wuthrich, K. (2005). Prion protein NMR structures of chickens, turtles, and frogs. Proc Natl Acad Sci U S A, Vol. 102, No. 3, pp. $651-5$

Cancellotti, E., Bradford, B. M., Tuzi, N. L., Hickey, R. D., Brown, D., Brown, K. L., Barron, R. M., Kisielewski, D., Piccardo, P. \& Manson, J. C. (2010). Glycosylation of PrPC determines timing of neuroinvasion and targeting in the brain following transmissible spongiform encephalopathy infection by a peripheral route. J Virol, Vol. 84, No. 7, pp. 3464-75

Cancellotti, E., Wiseman, F., Tuzi, N. L., Baybutt, H., Monaghan, P., Aitchison, L., Simpson, J. \& Manson, J. C. (2005). Altered glycosylated PrP proteins can have different neuronal trafficking in brain but do not acquire scrapie-like properties. J Biol Chem, Vol. 280, No. 52, pp. 42909-18

Capellari, S., Zaidi, S. I., Long, A. C., Kwon, E. E. \& Petersen, R. B. (2000). The Thr183Ala Mutation, Not the Loss of the First Glycosylation Site, Alters the Physical Properties of the Prion Protein. J Alzheimers Dis, Vol. 2, No. 1, pp. 27-35

Castilla, J., Saa, P., Hetz, C. \& Soto, C. (2005). In vitro generation of infectious scrapie prions. Cell, Vol. 121, No. 2, pp. 195-206 
Caughey, B., Baron, G. S., Chesebro, B. \& Jeffrey, M. (2009). Getting a grip on prions: oligomers, amyloids, and pathological membrane interactions. Annu Rev Biochem, Vol. 78, pp. 177-204

Caughey, B. \& Lansbury, P. T. (2003). Protofibrils, pores, fibrils, and neurodegeneration: separating the responsible protein aggregates from the innocent bystanders. Annu Rev Neurosci, Vol. 26, pp. 267-98

Caughey, B. W., Dong, A., Bhat, K. S., Ernst, D., Hayes, S. F. \& Caughey, W. S. (1991). Secondary structure analysis of the scrapie-associated protein PrP 27-30 in water by infrared spectroscopy. Biochemistry, Vol. 30, No. 31, pp. 7672-80

Caughey, W. S., Raymond, L. D., Horiuchi, M. \& Caughey, B. (1998). Inhibition of proteaseresistant prion protein formation by porphyrins and phthalocyanines. Proc Natl Acad Sci U S A, Vol. 95, No. 21, pp. 12117-22

Chang Ling, T. \& Stone, J. (1991). Factors determining the morphology and distribution of astrocytes in the cat retina: a 'contact-spacing' model of astrocyte interaction. J Comp Neurol, Vol. 303, No. 3, pp. 387-99

Chesebro, B., Trifilo, M., Race, R., Meade-White, K., Teng, C., LaCasse, R., Raymond, L., Favara, C., Baron, G., Priola, S., Caughey, B., Masliah, E. \& Oldstone, M. (2005). Anchorless prion protein results in infectious amyloid disease without clinical scrapie. Science, Vol. 308, No. 5727, pp. 1435-9

Chiesa, R., Piccardo, P., Ghetti, B. \& Harris, D. A. (1998). Neurological illness in transgenic mice expressing a prion protein with an insertional mutation. Neuron, Vol. 21, No. 6, pp. 1339-51

Chiti, Z., Knutsen, O. M., Betmouni, S. \& Greene, J. R. (2006). An integrated, temporal study of the behavioural, electrophysiological and neuropathological consequences of murine prion disease. Neurobiol Dis, Vol. 22, No. 2, pp. 363-73

Christen, B., Perez, D. R., Hornemann, S. \& Wuthrich, K. (2008). NMR structure of the bank vole prion protein at 20 degrees $C$ contains a structured loop of residues 165-171. J Mol Biol, Vol. 383, No. 2, pp. 306-12

Colby, D. W., Zhang, Q., Wang, S., Groth, D., Legname, G., Riesner, D. \& Prusiner, S. B. (2007). Prion detection by an amyloid seeding assay. Proc Natl Acad Sci U S A, Vol. 104, No. 52, pp. 20914-9

Colling, S. B., Collinge, J. \& Jefferys, J. G. (1996). Hippocampal slices from prion protein null mice: disrupted $\mathrm{Ca}(2+)$-activated K+ currents. Neurosci Lett, Vol. 209, No. 1, pp. 49-52

Cunningham, C., Deacon, R., Wells, H., Boche, D., Waters, S., Diniz, C. P., Scott, H., Rawlins, J. N. \& Perry, V. H. (2003). Synaptic changes characterize early behavioural signs in the ME7 model of murine prion disease. Eur J Neurosci, Vol. 17, No. 10, pp. 2147-55

Cunningham, C., Wilcockson, D. C., Campion, S., Lunnon, K. \& Perry, V. H. (2005). Central and systemic endotoxin challenges exacerbate the local inflammatory response and increase neuronal death during chronic neurodegeneration. J Neurosci, Vol. 25, No. 40, pp. $9275-84$

Curtis, J., Errington, M., Bliss, T., Voss, K. \& MacLeod, N. (2003). Age-dependent loss of PTP and LTP in the hippocampus of PrP-null mice. Neurobiol Dis, Vol. 13, No. 1, pp. 55-62

DeArmond, S. J., Sanchez, H., Yehiely, F., Qiu, Y., Ninchak-Casey, A., Daggett, V., Camerino, A. P., Cayetano, J., Rogers, M., Groth, D., Torchia, M., Tremblay, P., Scott, M. R., Cohen, F. E. \& Prusiner, S. B. (1997). Selective neuronal targeting in prion disease. Neuron, Vol. 19, No. 6, pp. 1337-48 
Deleault, N. R., Harris, B. T., Rees, J. R. \& Supattapone, S. (2007). Formation of native prions from minimal components in vitro. Proc Natl Acad Sci U S A, Vol. 104, No. 23, pp. 9741-6

Demaimay, R., Chesebro, B. \& Caughey, B. (2000). Inhibition of formation of proteaseresistant prion protein by Trypan Blue, Sirius Red and other Congo Red analogs. Arch Virol Suppl, Vol. No. 16, pp. 277-83

Demaimay, R., Harper, J., Gordon, H., Weaver, D., Chesebro, B. \& Caughey, B. (1998). Structural aspects of Congo red as an inhibitor of protease-resistant prion protein formation. J Neurochem, Vol. 71, No. 6, pp. 2534-41

Edgeworth, J. A., Gros, N., Alden, J., Joiner, S., Wadsworth, J. D., Linehan, J., Brandner, S., Jackson, G. S., Weissmann, C. \& Collinge, J. (2010). Spontaneous generation of mammalian prions. Proc Natl Acad Sci U S A, Vol. 107, No. 32, pp. 14402-6

Eghiaian, F., Grosclaude, J., Lesceu, S., Debey, P., Doublet, B., Treguer, E., Rezaei, H. \& Knossow, M. (2004). Insight into the PrPC-->PrPsc conversion from the structures of antibody-bound ovine prion scrapie-susceptibility variants. Proc Natl Acad Sci U S A, Vol. 101, No. 28, pp. 10254-9

Eiden, M., Soto, E. O., Mettenleiter, T. C. \& Groschup, M. H. (2011). Effects of polymorphisms in ovine and caprine prion protein alleles on cell-free conversion. Vet Res, Vol. 42, No. 1, pp. 30

Fischer, M., Rulicke, T., Raeber, A., Sailer, A., Moser, M., Oesch, B., Brandner, S., Aguzzi, A. \& Weissmann, C. (1996). Prion protein (PrP) with amino-proximal deletions restoring susceptibility of PrP knockout mice to scrapie. Embo J, Vol. 15, No. 6, pp. 1255-64

Flechsig, E., Hegyi, I., Leimeroth, R., Zuniga, A., Rossi, D., Cozzio, A., Schwarz, P., Rulicke, T., Gotz, J., Aguzzi, A. \& Weissmann, C. (2003). Expression of truncated PrP targeted to Purkinje cells of PrP knockout mice causes Purkinje cell death and ataxia. Embo J, Vol. 22, No. 12, pp. 3095-101

Franklin, S. L., Love, S., Greene, J. R. \& Betmouni, S. (2008). Loss of Perineuronal Net in ME7 Prion Disease. J Neuropathol Exp Neurol, Vol. 67, No. 3, pp. 189-99

Fuhrmann, M., Bittner, T., Mitteregger, G., Haider, N., Moosmang, S., Kretzschmar, H. \& Herms, J. (2006). Loss of the cellular prion protein affects the Ca2+ homeostasis in hippocampal CA1 neurons. J Neurochem, Vol. 98, No. 6, pp. 1876-85

Gill, A. C., Agarwal, S., Pinheiro, T. J. \& Graham, J. F. (2010). Structural requirements for efficient prion protein conversion: cofactors may promote a conversion-competent structure for $\operatorname{PrP}(\mathrm{C})$. Prion, Vol. 4, No. 4, pp. 235-42

Gill, A. C., Ritchie, M. A., Hunt, L. G., Steane, S. E., Davies, K. G., Bocking, S. P., Rhie, A. G., Bennett, A. D. \& Hope, J. (2000). Post-translational hydroxylation at the N-terminus of the prion protein reveals presence of PPII structure in vivo. Embo J, Vol. 19, No. 20, pp. 5324-31

Gillingwater, T. H., Ingham, C. A., Coleman, M. P. \& Ribchester, R. R. (2003). Ultrastructural correlates of synapse withdrawal at axotomized neuromuscular junctions in mutant and transgenic mice expressing the Wld gene. Journal of Anatomy, Vol. 203, No. 3, pp. 265-276

Giorgi, A., Di Francesco, L., Principe, S., Mignogna, G., Sennels, L., Mancone, C., Alonzi, T., Sbriccoli, M., De Pascalis, A., Rappsilber, J., Cardone, F., Pocchiari, M., Maras, B. \& Schinina, M. E. (2009). Proteomic profiling of PrP27-30-enriched preparations extracted from the brain of hamsters with experimental scrapie. Proteomics, Vol. 9, No. 15, pp. 3802-14 
Gossert, A. D., Bonjour, S., Lysek, D. A., Fiorito, F. \& Wuthrich, K. (2005). Prion protein NMR structures of elk and of mouse/elk hybrids. Proc Natl Acad Sci U S A, Vol. 102, No. 3, pp. 646-50

Govaerts, C., Wille, H., Prusiner, S. B. \& Cohen, F. E. (2004). Evidence for assembly of prions with left-handed beta-helices into trimers. Proc Natl Acad Sci U S A, Vol. 101, No. 22, pp. 8342-7

Graham, J. F., Agarwal, S., Kurian, D., Kirby, L., Pinheiro, T. J. \& Gill, A. C. (2010). Low density subcellular fractions enhance disease-specific prion protein misfolding. $J$ Biol Chem, Vol. 285, No. 13, pp. 9868-80

Graham, J. F., Kurian, D., Agarwal, S., Toovey, L., Hunt, L., Kirby, L., Pinheiro, T., J. T., Banner, S. J. \& Gill, A. C. (2011). Na+/K+-ATPase is present in scrapie-associated fibrils, modulates PrP misfolding in vitro and links PrP function and dysfunction. PLOS One, Vol. 6, No. 11, pp. e26813

Graner, E., Mercadante, A. F., Zanata, S. M., Forlenza, O. V., Cabral, A. L., Veiga, S. S., Juliano, M. A., Roesler, R., Walz, R., Minetti, A., Izquierdo, I., Martins, V. R. \& Brentani, R. R. (2000). Cellular prion protein binds laminin and mediates neuritogenesis. Brain Res Mol Brain Res, Vol. 76, No. 1, pp. 85-92

Gray, B. C., Siskova, Z., Perry, V. H. \& O'Connor, V. (2009). Selective presynaptic degeneration in the synaptopathy associated with ME7-induced hippocampal pathology. Neurobiol Dis, Vol. 35, No. 1, pp. 63-74

Grosche, J., Matyash, V., Moller, T., Verkhratsky, A., Reichenbach, A. \& Kettenmann, H. (1999). Microdomains for neuron-glia interaction: parallel fiber signaling to Bergmann glial cells. Nat Neurosci, Vol. 2, No. 2, pp. 139-143

Guenther, K., Deacon, R. M., Perry, V. H. \& Rawlins, J. N. (2001). Early behavioural changes in scrapie-affected mice and the influence of dapsone. Eur J Neurosci, Vol. 14, No. 2, pp. 401-9

Haire, L. F., Whyte, S. M., Vasisht, N., Gill, A. C., Verma, C., Dodson, E. J., Dodson, G. G. \& Bayley, P. M. (2004). The crystal structure of the globular domain of sheep prion protein. J Mol Biol, Vol. 336, No. 5, pp. 1175-83

Hegde, R. S., Mastrianni, J. A., Scott, M. R., DeFea, K. A., Tremblay, P., Torchia, M., DeArmond, S. J., Prusiner, S. B. \& Lingappa, V. R. (1998). A transmembrane form of the prion protein in neurodegenerative disease. Science, Vol. 279, No. 5352, pp. 82734

Herms, J. W., Tings, T., Dunker, S. \& Kretzschmar, H. A. (2001). Prion protein affects Ca2+activated $\mathrm{K}+$ currents in cerebellar purkinje cells. Neurobiol Dis, Vol. 8, No. 2, pp. 324-30

Hooper, N. M. (2011). Glypican-1 facilitates prion conversion in lipid rafts. J Neurochem, Vol. 116, No. 5, pp. 721-5

Hope, J., Morton, L. J., Farquhar, C. F., Multhaup, G., Beyreuther, K. \& Kimberlin, R. H. (1986). The major polypeptide of scrapie-associated fibrils (SAF) has the same size, charge distribution and $\mathrm{N}$-terminal protein sequence as predicted for the normal brain protein (PrP). Embo J, Vol. 5, No. 10, pp. 2591-7

Horiuchi, M. \& Caughey, B. (1999). Specific binding of normal prion protein to the scrapie form via a localized domain initiates its conversion to the protease-resistant state. Embo J, Vol. 18, No. 12, pp. 3193-203 
Hornemann, S., Schorn, C. \& Wuthrich, K. (2004). NMR structure of the bovine prion protein isolated from healthy calf brains. EMBO Rep, Vol. 5, No. 12, pp. 1159-64

Ikeda, S., Kobayashi, A. \& Kitamoto, T. (2008). Thr but Asn of the N-glycosylation sites of PrP is indispensable for its misfolding. Biochem Biophys Res Commun, Vol. 369, No. 4, pp. 1195-8

Inouye, H., Bond, J., Baldwin, M. A., Ball, H. L., Prusiner, S. B. \& Kirschner, D. A. (2000). Structural changes in a hydrophobic domain of the prion protein induced by hydration and by ala-->Val and pro-->Leu substitutions. J Mol Biol, Vol. 300, No. 5, pp. 1283-96

Jeffrey, M., Halliday, W. G., Bell, J., Johnston, A. R., MacLeod, N. K., Ingham, C., Sayers, A. R., Brown, D. A. \& Fraser, J. R. (2000). Synapse loss associated with abnormal PrP precedes neuronal degeneration in the scrapie-infected murine hippocampus. Neuropathol Appl Neurobiol, Vol. 26, No. 1, pp. 41-54

Jeffrey, M., McGovern, G., Siso, S. \& Gonzalez, L. (2011). Cellular and sub-cellular pathology of animal prion diseases: relationship between morphological changes, accumulation of abnormal prion protein and clinical disease. Acta Neuropathologica, Vol. 121, No. 1, pp. 113-134

Kayed, R., Sokolov, Y., Edmonds, B., McIntire, T. M., Milton, S. C., Hall, J. E. \& Glabe, C. G. (2004). Permeabilization of lipid bilayers is a common conformation-dependent activity of soluble amyloid oligomers in protein misfolding diseases. J Biol Chem, Vol. 279, No. 45, pp. 46363-6

Kirby, L., Agarwal, S., Graham, J. F., Goldmann, W. \& Gill, A. C. (2010). Inverse correlation of thermal lability and conversion efficiency for five prion protein polymorphic variants. Biochemistry, Vol. 49, No. 7, pp. 1448-59

Kirby, L., Birkett, C. R., Rudyk, H., Gilbert, I. H. \& Hope, J. (2003). In vitro cell-free conversion of bacterial recombinant PrP to PrPres as a model for conversion. J Gen Virol, Vol. 84, No. 4, pp. 1013-20

Kirby, L., Goldmann, W., Houston, F., Gill, A. C. \& Manson, J. C. (2006). A novel, resistancelinked ovine PrP variant and its equivalent mouse variant modulate the in vitro cell-free conversion of $\mathrm{rPrP}$ to $\operatorname{PrP}(\mathrm{res})$. J Gen Virol, Vol. 87, No. 12, pp. 3747-51

Knaus, K. J., Morillas, M., Swietnicki, W., Malone, M., Surewicz, W. K. \& Yee, V. C. (2001). Crystal structure of the human prion protein reveals a mechanism for oligomerization. Nat Struct Biol, Vol. 8, No. 9, pp. 770-4

Kocisko, D. A., Come, J. H., Priola, S. A., Chesebro, B., Raymond, G. J., Lansbury, P. T. \& Caughey, B. (1994). Cell-free formation of protease-resistant prion protein. Nature, Vol. 370, No. 6489, pp. 471-4

Kocisko, D. A., Priola, S. A., Raymond, G. J., Chesebro, B., Lansbury, P. T., Jr. \& Caughey, B. (1995). Species specificity in the cell-free conversion of prion protein to proteaseresistant forms: a model for the scrapie species barrier. Proc Natl Acad Sci U S A, Vol. 92, No. 9, pp. 3923-7

Kreft, M., Potokar, M., Pangrsic, T., Stenovec, M. \& Zorec, R. (2009). Properties of Regulated Exocytosis and Vesicle Trafficking in Astrocytes. Glia, Vol. 57, No. 13, pp. S32-S32

Lasmezas, C. I., Deslys, J. P., Robain, O., Jaegly, A., Beringue, V., Peyrin, J. M., Fournier, J. G., Hauw, J. J., Rossier, J. \& Dormont, D. (1997). Transmission of the BSE agent to mice in the absence of detectable abnormal prion protein. Science, Vol. 275, No. 5298 , pp. 402-5 
Lee, S., Antony, L., Hartmann, R., Knaus, K. J., Surewicz, K., Surewicz, W. K. \& Yee, V. C. (2010). Conformational diversity in prion protein variants influences intermolecular beta-sheet formation. Embo J, Vol. 29, No. 1, pp. 251-62

Legname, G., Baskakov, I. V., Nguyen, H. O., Riesner, D., Cohen, F. E., DeArmond, S. J. \& Prusiner, S. B. (2004). Synthetic mammalian prions. Science, Vol. 305, No. 5684, pp. 673-6

Lehmann, S. \& Harris, D. A. (1997). Blockade of glycosylation promotes acquisition of scrapie-like properties by the prion protein in cultured cells. J Biol Chem, Vol. 272, No. 34, pp. 21479-87

Li, A., Christensen, H. M., Stewart, L. R., Roth, K. A., Chiesa, R. \& Harris, D. A. (2007). Neonatal lethality in transgenic mice expressing prion protein with a deletion of residues 105-125. Embo J, Vol. 26, No. 2, pp. 548-58

Lopes, M. H., Hajj, G. N., Muras, A. G., Mancini, G. L., Castro, R. M., Ribeiro, K. C., Brentani, R. R., Linden, R. \& Martins, V. R. (2005). Interaction of cellular prion and stressinducible protein 1 promotes neuritogenesis and neuroprotection by distinct signaling pathways. J Neurosci, Vol. 25, No. 49, pp. 11330-9

Lysek, D. A., Schorn, C., Nivon, L. G., Esteve-Moya, V., Christen, B., Calzolai, L., von Schroetter, C., Fiorito, F., Herrmann, T., Guntert, P. \& Wuthrich, K. (2005). Prion protein NMR structures of cats, dogs, pigs, and sheep. Proc Natl Acad Sci U S A, Vol. 102, No. 3, pp. 640-5

Ma, J., Wollmann, R. \& Lindquist, S. (2002). Neurotoxicity and neurodegeneration when PrP accumulates in the cytosol. Science, Vol. 298, No. 5599, pp. 1781-5

Maglio, L. E., Martins, V. R., Izquierdo, I. \& Ramirez, O. A. (2006). Role of cellular prion protein on LTP expression in aged mice. Brain Res, Vol. 1097, No. 1, pp. 11-8

Makarava, N., Kovacs, G. G., Bocharova, O., Savtchenko, R., Alexeeva, I., Budka, H., Rohwer, R. G. \& Baskakov, I. V. (2010). Recombinant prion protein induces a new transmissible prion disease in wild-type animals. Acta Neuropathol, Vol. 119, No. 2, pp. 177-87

Makarava, N., Lee, C. I., Ostapchenko, V. G. \& Baskakov, I. V. (2007). Highly promiscuous nature of prion polymerization. J Biol Chem, Vol. 282, No. 50, pp. 36704-13

Mallucci, G., Dickinson, A., Linehan, J., Klohn, P. C., Brandner, S. \& Collinge, J. (2003). Depleting neuronal PrP in prion infection prevents disease and reverses spongiosis. Science, Vol. 302, No. 5646, pp. 871-4

Manson, J. C., Barron, R. M., Thomson, V., Jamieson, E., Melton, D. W., Ironside, J. \& Will, R. (2001). Changing a single amino acid in the N-terminus of murine PrP alters TSE incubation time across three species barriers. Embo J, Vol. 20, No. 18, pp. 5070-5078

Manson, J. C., Clarke, A. R., Hooper, M. L., Aitchison, L., Mcconnell, I. \& Hope, J. (1994a). 129/Ola Mice Carrying a Null Mutation in Prp That Abolishes Messenger-Rna Production Are Developmentally Normal. Mol Neurobiol, Vol. 8, No. 2-3, pp. 121127

Manson, J. C., Clarke, A. R., McBride, P. A., McConnell, I. \& Hope, J. (1994b). PrP gene dosage determines the timing but not the final intensity or distribution of lesions in scrapie pathology. Neurodegeneration, Vol. 3, No. 4, pp. 331-40 
Martins, I. C., Kuperstein, I., Wilkinson, H., Maes, E., Vanbrabant, M., Jonckheere, W., Van Gelder, P., Hartmann, D., D'Hooge, R., De Strooper, B., Schymkowitz, J. \& Rousseau, F. (2008). Lipids revert inert Abeta amyloid fibrils to neurotoxic protofibrils that affect learning in mice. Embo J, Vol. 27, No. 1, pp. 224-33

Miele, G., Jeffrey, M., Turnbull, D., Manson, J. \& Clinton, M. (2002). Ablation of cellular prion protein expression affects mitochondrial numbers and morphology. Biochem Biophys Res Commun, Vol. 291, No. 2, pp. 372-7

Moore, R. A., Timmes, A., Wilmarth, P. A. \& Priola, S. A. (2010). Comparative profiling of highly enriched 22L and Chandler mouse scrapie prion protein preparations. Proteomics, Vol. 10, No. 15, pp. 2858-69

Muramoto, T., DeArmond, S. J., Scott, M., Telling, G. C., Cohen, F. E. \& Prusiner, S. B. (1997). Heritable disorder resembling neuronal storage disease in mice expressing prion protein with deletion of an alpha-helix. Nat Med, Vol. 3, No. 7, pp. 750-5

Nadal, R. C., Davies, P., Brown, D. R. \& Viles, J. H. (2009). Evaluation of copper2+ affinities for the prion protein. Biochemistry, Vol. 48, No. 38, pp. 8929-31

Neuendorf, E., Weber, A., Saalmueller, A., Schatzl, H., Reifenberg, K., Pfaff, E. \& Groschup, M. H. (2004). Glycosylation deficiency at either one of the two glycan attachment sites of cellular prion protein preserves susceptibility to bovine spongiform encephalopathy and scrapie infections. J Biol Chem, Vol. 279, No. 51, pp. 53306-16

Nishina, K. A., Deleault, N. R., Mahal, S. P., Baskakov, I., Luhrs, T., Riek, R. \& Supattapone, S. (2006). The stoichiometry of host PrPC glycoforms modulates the efficiency of PrPsc formation in vitro. Biochemistry, Vol. 45, No. 47, pp. 14129-39

Novitskaya, V., Bocharova, O. V., Bronstein, I. \& Baskakov, I. V. (2006). Amyloid fibrils of mammalian prion protein are highly toxic to cultured cells and primary neurons. $J$ Biol Chem, Vol. 281, No. 19, pp. 13828-36

Paludi, D., Thellung, S., Chiovitti, K., Corsaro, A., Villa, V., Russo, C., Ianieri, A., Bertsch, U., Kretzschmar, H. A., Aceto, A. \& Florio, T. (2007). Different structural stability and toxicity of $\operatorname{PrP}(\mathrm{ARR})$ and $\operatorname{PrP}(\mathrm{ARQ})$ sheep prion protein variants. J Neurochem, Vol. 103, No. 6, pp. 2291-300

Pauly, P. C. \& Harris, D. A. (1998). Copper stimulates endocytosis of the prion protein. J Biol Chem, Vol. 273, No. 50, pp. 33107-10

Pekny, M., Li, L. Z., Lundkvist, A., Andersson, D., Wilhelmsson, U., Nagai, N., Pardo, A. C., Nodin, C., Stahlberg, A., Aprico, K., Larsson, K., Yabe, T., Moons, L., Fotheringham, A., Davies, I., Carmeliet, P., Schwartz, J. P., Pekna, M., Kubista, M., Blomstrand, F., Maragakis, N. \& Nilsson, M. (2008). Protective role of reactive astrocytes in brain ischemia. J Cereb Blood Flow Metab, Vol. 28, No. 3, pp. 468-481

Perez, D. R., Damberger, F. F. \& Wuthrich, K. (2010). Horse prion protein NMR structure and comparisons with related variants of the mouse prion protein. J Mol Biol, Vol. 400 , No. 2 , pp. $121-8$

Perry, V. H., Cunningham, C. \& Boche, D. (2002). Atypical inflammation in the central nervous system in prion disease. Curr Opin Neurol, Vol. 15, No. 3, pp. 349-354

Perry, V. H., Cunningham, C. \& Holmes, C. (2007). Systemic infections and inflammation affect chronic neurodegeneration. Nat Rev Immunol, Vol. 7, No. 2, pp. 161-167

Perry, V. H., Newman, T. A. \& Cunningham, C. (2003). The impact of systemic infection on the progression of neurodegenerative disease. Nat Rev Neurosci, Vol. 4, No. 2, pp. 103-112 
Perry, V. H. \& O'Connor, V. (2010). The role of microglia in synaptic stripping and synaptic degeneration: a revised perspective. Asn Neuro, Vol. 2, No. 5, pp. 281-291

Petrakis, S., Malinowska, A., Dadlez, M. \& Sklaviadis, T. (2009). Identification of proteins copurifying with scrapie infectivity. J Proteomics, Vol. 72, No. 4, pp. 690-4

Piccardo, P., Manson, J. C., King, D., Ghetti, B. \& Barron, R. M. (2007). Accumulation of prion protein in the brain that is not associated with transmissible disease. Proc Natl Acad Sci U S A, Vol. 104, No. 11, pp. 4712-7

Piro, J. R., Harris, B. T., Nishina, K., Soto, C., Morales, R., Rees, J. R. \& Supattapone, S. (2009). Prion protein glycosylation is not required for strain-specific neurotropism. J Virol, Vol. 83, No. 11, pp. 5321-8

Priola, S. A. \& Lawson, V. A. (2001). Glycosylation influences cross-species formation of protease-resistant prion protein. Embo J, Vol. 20, No. 23, pp. 6692-9

Prusiner, S. B. (1998). Prions. Proc Natl Acad Sci U S A, Vol. 95, No. 23, pp. 13363-13383

Quist, A., Doudevski, I., Lin, H., Azimova, R., Ng, D., Frangione, B., Kagan, B., Ghiso, J. \& Lal, R. (2005). Amyloid ion channels: a common structural link for proteinmisfolding disease. Proc Natl Acad Sci U S A, Vol. 102, No. 30, pp. 10427-32

Raeber, A. J., Race, R. E., Brandner, S., Priola, S. A., Sailer, A., Bessen, R. A., Mucke, L., Manson, J., Aguzzi, A., Oldstone, M. B., Weissmann, C. \& Chesebro, B. (1997). Astrocyte-specific expression of hamster prion protein (PrP) renders PrP knockout mice susceptible to hamster scrapie. Embo J, Vol. 16, No. 20, pp. 6057-65

Ransom, B., Behar, T. \& Nedergaard, M. (2003). New roles for astrocytes (stars at last). Tr Neurosci, Vol. 26, No. 10, pp. 520-2

Resenberger, U. K., Harmeier, A., Woerner, A. C., Goodman, J. L., Muller, V., Krishnan, R., Vabulas, R. M., Kretzschmar, H. A., Lindquist, S., Hartl, F. U., Multhaup, G., Winklhofer, K. F. \& Tatzelt, J. (2011a). The cellular prion protein mediates neurotoxic signalling of beta-sheet-rich conformers independent of prion replication. Embo J, Vol. 30, No. 10, pp. 2057-70

Resenberger, U. K., Winklhofer, K. F. \& Tatzelt, J. (2011b). Neuroprotective and Neurotoxic Signaling by the Prion Protein. Top Curr Chem, Vol. Prion Proteins, No. 305, pp. 101119

Rezaei, H. (2008). Prion protein oligomerization. Curr Alzheimer Res, Vol. 5, No. 6, pp. 572-8

Ritchie, M. A., Gill, A. C., Deery, M. J. \& Lilley, K. (2002). Precursor ion scanning for detection and structural characterization of heterogeneous glycopeptide mixtures. $J$ Am Soc Mass Spectrom, Vol. 13, No. 9, pp. 1065-77

Robinson, S. R. \& Dreher, Z. (1989). Evidence for three morphological classes of astrocyte in the adult rabbit retina: functional and developmental implications. Neuroscience Letters, Vol. 106, No. 3, pp. 261-8

Rossetti, G., Cong, X., Caliandro, R., Legname, G. \& Carloni, P. (2011). Common Structural Traits across Pathogenic Mutants of the Human Prion Protein and Their Implications for Familial Prion Diseases. J Mol Biol, Vol. 411, No. 3, pp. 700-712

Rudd, P. M., Endo, T., Colominas, C., Groth, D., Wheeler, S. F., Harvey, D. J., Wormald, M. R., Serban, H., Prusiner, S. B., Kobata, A. \& Dwek, R. A. (1999). Glycosylation differences between the normal and pathogenic prion protein isoforms. Proc Natl Acad Sci U S A, Vol. 96, No. 23, pp. 13044-9

Rudd, P. M., Merry, A. H., Wormald, M. R. \& Dwek, R. A. (2002). Glycosylation and prion protein. Curr Opin Struct Biol, Vol. 12, No. 5, pp. 578-86 
Saa, P., Castilla, J. \& Soto, C. (2006). Ultra-efficient replication of infectious prions by automated protein misfolding cyclic amplification. J Biol Chem, Vol. 281, No. 46, pp. 35245-52

Saborio, G. P., Permanne, B. \& Soto, C. (2001). Sensitive detection of pathological prion protein by cyclic amplification of protein misfolding. Nature, Vol. 411, No. 6839, pp. $810-3$

Salamat, M. K., Dron, M., Chapuis, J., Langevin, C. \& Laude, H. (2011). Prion propagation in cells expressing PrP glycosylation mutants. J Virol, Vol. 85, No. 7, pp. 3077-85

Sanghera, N., Wall, M., Venien-Bryan, C. \& Pinheiro, T. J. (2008). Globular and pre-fibrillar prion aggregates are toxic to neuronal cells and perturb their electrophysiology. Biochim Biophys Acta, Vol. 1784, No. 6, pp. 873-81

Shmerling, D., Hegyi, I., Fischer, M., Blattler, T., Brandner, S., Gotz, J., Rulicke, T., Flechsig, E., Cozzio, A., von Mering, C., Hangartner, C., Aguzzi, A. \& Weissmann, C. (1998). Expression of amino-terminally truncated $\operatorname{PrP}$ in the mouse leading to ataxia and specific cerebellar lesions. Cell, Vol. 93, No. 2, pp. 203-14

Silveira, J. R., Raymond, G. J., Hughson, A. G., Race, R. E., Sim, V. L., Hayes, S. F. \& Caughey, B. (2005). The most infectious prion protein particles. Nature, Vol. 437, No. 7056, pp. 257-61

Simoneau, S., Rezaei, H., Sales, N., Kaiser-Schulz, G., Lefebvre-Roque, M., Vidal, C., Fournier, J. G., Comte, J., Wopfner, F., Grosclaude, J., Schatzl, H. \& Lasmezas, C. I. (2007). In vitro and in vivo neurotoxicity of prion protein oligomers. PLoS Pathog, Vol. 3, No. 8, pp. e125

Siskova, Z., Page, A., O'Connor, V. \& Perry, V. H. (2009). Degenerating synaptic boutons in prion disease: microglia activation without synaptic stripping. Am J Pathol, Vol. 175, No. 4, pp. $1610-21$

Slezak, M. \& Pfrieger, F. W. (2003). New roles for astrocytes: regulation of CNS synaptogenesis. Tr Neurosci, Vol. 26, No. 10, pp. 531-5

Smirnovas, V., Baron, G. S., Offerdahl, D. K., Raymond, G. J., Caughey, B. \& Surewicz, W. K. (2011). Structural organization of brain-derived mammalian prions examined by hydrogen-deuterium exchange. Nat Struct Mol Biol, Vol. 18, No. 4, pp. 504-6

Solito, E., McArthur, S., Cristante, E., Paterno, M., Christian, H., Roncaroli, F. \& Gillies, G. E. (2010). Annexin A1: A Central Player in the Anti-Inflammatory and Neuroprotective Role of Microglia. J Immunol, Vol. 185, No. 10, pp. 6317-6328

Stimson, E., Hope, J., Chong, A. \& Burlingame, A. L. (1999). Site-specific characterization of the N-linked glycans of murine prion protein by high-performance liquid chromatography/electrospray mass spectrometry and exoglycosidase digestions. Biochemistry, Vol. 38, No. 15, pp. 4885-95

Stohr, J., Elfrink, K., Weinmann, N., Wille, H., Willbold, D., Birkmann, E. \& Riesner, D. (2011). In vitro conversion and seeded fibrillization of posttranslationally modified prion protein. Biol Chem, Vol. 392, No. 5, pp. 415-21

Tahiri-Alaoui, A., Gill, A. C., Disterer, P. \& James, W. (2004). Methionine 129 variant of human prion protein oligomerizes more rapidly than the valine 129 variant: implications for disease susceptibility to Creutzfeldt-Jakob disease. J Biol Chem, Vol. 279, No. 30, pp. 31390-7 
Tahiri-Alaoui, A., Sim, V. L., Caughey, B. \& James, W. (2006). Molecular heterosis of prion protein beta-oligomers. A potential mechanism of human resistance to disease. $J$ Biol Chem, Vol. 281, No. 45, pp. 34171-8

Tanaka, M., Collins, S. R., Toyama, B. H. \& Weissman, J. S. (2006). The physical basis of how prion conformations determine strain phenotypes. Nature, Vol. 442, No. 7102, pp. $585-9$

Taubner, L. M., Bienkiewicz, E. A., Copie, V. \& Caughey, B. (2010). Structure of the flexible amino-terminal domain of prion protein bound to a sulfated glycan. J Mol Biol, Vol. 395, No. 3, pp. 475-90

Thackray, A. M., Yang, S., Wong, E., Fitzmaurice, T. J., Morgan-Warren, R. J. \& Bujdoso, R. (2004). Conformational variation between allelic variants of cell-surface ovine prion protein. Biochem J, Vol. 381, No. 1, pp. 221-9

Tobler, I., Gaus, S. E., Deboer, T., Achermann, P., Fischer, M., Rulicke, T., Moser, M., Oesch, B., McBride, P. A. \& Manson, J. C. (1996). Altered circadian activity rhythms and sleep in mice devoid of prion protein. Nature, Vol. 380, No. 6575, pp. 639-42

Tuzi, N. L., Cancellotti, E., Baybutt, H., Blackford, L., Bradford, B., Plinston, C., Coghill, A., Hart, P., Piccardo, P., Barron, R. M. \& Manson, J. C. (2008). Host PrP glycosylation: a major factor determining the outcome of prion infection. PLoS Biol, Vol. 6, No. 4, pp. e100

Tuzi, N. L., Clarke, A. R., Bradford, B., Aitchison, L., Thomson, V. \& Manson, J. C. (2004). Cre-loxP mediated control of $\operatorname{PrP}$ to study transmissible spongiform encephalopathy diseases. Genesis, Vol. 40, No. 1, pp. 1-6

van der Kamp, M. W. \& Daggett, V. (2010). Pathogenic mutations in the hydrophobic core of the human prion protein can promote structural instability and misfolding. J Mol Biol, Vol. 404, No. 4, pp. 732-48

Vanik, D. L. \& Surewicz, W. K. (2002). Disease-associated F198S mutation increases the propensity of the recombinant prion protein for conformational conversion to scrapie-like form. J Biol Chem, Vol. 277, No. 50, pp. 49065-70

Waggoner, D. J., Drisaldi, B., Bartnikas, T. B., Casareno, R. L., Prohaska, J. R., Gitlin, J. D. \& Harris, D. A. (2000). Brain copper content and cuproenzyme activity do not vary with prion protein expression level. J Biol Chem, Vol. 275, No. 11, pp. 7455-8

Wang, F., Wang, X., Yuan, C. G. \& Ma, J. (2010). Generating a prion with bacterially expressed recombinant prion protein. Science, Vol. 327, No. 5969, pp. 1132-5

Weber, P., Giese, A., Piening, N., Mitteregger, G., Thomzig, A., Beekes, M. \& Kretzschmar, H. A. (2007). Generation of genuine prion infectivity by serial PMCA. Vet Microbiol, Vol. 123, No. 4, pp. 346-57

Weissmann, C. (1991). A 'unified theory' of prion propagation. Nature, Vol. 352, No. 6337, pp. $679-83$

Whittal, R. M., Ball, H. L., Cohen, F. E., Burlingame, A. L., Prusiner, S. B. \& Baldwin, M. A. (2000). Copper binding to octarepeat peptides of the prion protein monitored by mass spectrometry. Protein Sci, Vol. 9, No. 2, pp. 332-43

Wille, H., Michelitsch, M. D., Guenebaut, V., Supattapone, S., Serban, A., Cohen, F. E., Agard, D. A. \& Prusiner, S. B. (2002). Structural studies of the scrapie prion protein by electron crystallography. Proc Natl Acad Sci U S A, Vol. 99, No. 6, pp. 3563-8 
Wong, B. S., Venien-Bryan, C., Williamson, R. A., Burton, D. R., Gambetti, P., Sy, M. S., Brown, D. R. \& Jones, I. M. (2000a). Copper refolding of prion protein. Biochem Biophys Res Commun, Vol. 276, No. 3, pp. 1217-24

Wong, N. K., Renouf, D. V., Lehmann, S. \& Hounsell, E. F. (2000b). Glycosylation of prions and its effects on protein conformation relevant to amino acid mutations. J Mol Graph Model, Vol. 18, No. 2, pp. 126-34, 163-5

Wuthrich, K. \& Riek, R. (2001). Three-dimensional structures of prion proteins. Adv Protein Chem, Vol. 57, No. pp. 55-82

Yin, S., Pham, N., Yu, S., Li, C., Wong, P., Chang, B., Kang, S. C., Biasini, E., Tien, P., Harris, D. A. \& Sy, M. S. (2007). Human prion proteins with pathogenic mutations share common conformational changes resulting in enhanced binding to glycosaminoglycans. Proc Natl Acad Sci U S A, Vol. 104, No. 18, pp. 7546-51

Zhang, C., Jackson, A. P., Zhang, Z. R., Han, Y., Yu, S., He, R. Q. \& Perrett, S. (2010). Amyloid-like aggregates of the yeast prion protein ure 2 enter vertebrate cells by specific endocytotic pathways and induce apoptosis. PLoS One, Vol. 5, No. 9, pp e12529. 


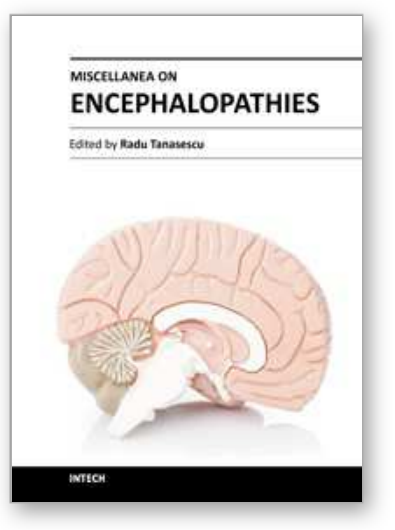

\author{
Miscellanea on Encephalopathies \\ Edited by Dr. Radu Tanasescu
}

ISBN 978-953-51-0499-5

Hard cover, 202 pages

Publisher InTech

Published online 18, April, 2012

Published in print edition April, 2012

The book project "Miscellanea on Encephalopathies" aims to cover some of the important aspects of infectious-related encephalopathies, post-transplantation and drug-induced encephalopathies, by transmitting valuable information filtered through the real life clinical and research experience of the authors.

\title{
How to reference
}

In order to correctly reference this scholarly work, feel free to copy and paste the following:

Fiona Lane, James Alibhai, Jean C. Manson and Andrew C. Gill (2012). Mechanisms of Cell Death in the Transmissible Spongiform Encephalopathies, Miscellanea on Encephalopathies, Dr. Radu Tanasescu (Ed.), ISBN: 978-953-51-0499-5, InTech, Available from: http://www.intechopen.com/books/miscellanea-onencephalopathies/mechanisms-of-cell-death-in-the-transmissible-spongiform-encephalopathies

\section{INTECH}

open science | open minds

\section{InTech Europe}

University Campus STeP Ri

Slavka Krautzeka 83/A

51000 Rijeka, Croatia

Phone: +385 (51) 770447

Fax: +385 (51) 686166

www.intechopen.com

\section{InTech China}

Unit 405, Office Block, Hotel Equatorial Shanghai

No.65, Yan An Road (West), Shanghai, 200040, China

中国上海市延安西路65号上海国际贵都大饭店办公楼405单元

Phone: +86-21-62489820

Fax: $+86-21-62489821$ 
(C) 2012 The Author(s). Licensee IntechOpen. This is an open access article distributed under the terms of the Creative Commons Attribution 3.0 License, which permits unrestricted use, distribution, and reproduction in any medium, provided the original work is properly cited. 